\title{
Indoor Airborne Microbial Load of Selected Offices in a Tertiary Institution in South-Western Nigeria
}

\author{
Akindele Oluwakemi Omolola ${ }^{1}$, Ana Godson Rowland ${ }^{1}$, Uchendu Obioma Chukwudi ${ }^{2}$, \\ Fakunle Adekunle Gregory ${ }^{1,3,{ }^{*}}$, Bello Temilade Basirat ${ }^{4}$ \\ ${ }^{1}$ Department of Environmental Health Sciences, University of Ibadan, Ibadan, Nigeria \\ ${ }^{2}$ Department of Community Medicine, University of Ibadan, Ibadan, Nigeria \\ ${ }^{3}$ Environmental Health Unit, Blue-gate Public Health Initiative, Ibadan, Nigeria \\ ${ }^{4}$ Department of Community Medicine, Osun State University, Osun, Nigeria
}

Email address:

fakunz@yahoo.com (F. A. Gregory)

*Corresponding author

\section{To cite this article:}

Akindele Oluwakemi Omolola, Ana Godson Rowland, Uchendu Obioma Chukwudi, Fakunle Adekunle Gregory, Adegoke Temilade Bello. Indoor Airborne Microbial Load of Selected Offices in a Tertiary Institution in South-Western Nigeria. Journal of Health and Environmental Research. Vol. 4, No. 3, 2018, pp. 113-118. doi: 10.11648/j.jher.20180403.15

Received: July 24, 2018; Accepted: August 7, 2018; Published: September 3, 2018

\begin{abstract}
Indoor air quality (IAQ) has been identified by the Environmental Protection Agency (EPA) as one of the most urgent top five environmental risks to public health. Numerous studies have documented that sick building syndrome (SBS) is surprisingly common even in buildings without widespread complaints and its relationship with hypersensitivity disease are often associated with exposure to high concentration of airborne microbial organisms. To contribute to knowledge on IAQ, this study evaluates the levels and composition of bacterial and fungal contamination of different offices in a tertiary institution in South-western Nigeria. A cross sectional design was used to compare the indoor airborne microbial load of three categories of offices within the institution premises: the central administrative (CA), academic (AC) and work and maintenance (W\&M) offices. Indoor temperature $\left({ }^{\circ} \mathrm{C}\right)$ and relative humidity $(\%)$ of the respective offices were measured using a 5-in-1 multi-tester N21FR made in China and categorized into comfort and high levels. Air samples were collected using a TE-10-890 Andersen single stage microbial air sampler and the total counts per cubic metre were compared with the American Industrial Hygiene Association guideline (AIHA). Data were analyzed using descriptive statistics, t-test, Spearman's rank correlation and regression analysis. Offices in CA recorded the highest mean indoor Total Bacteria Count (TBC) of $22.6 \pm 12.2 \mathrm{cfu} / \mathrm{m}^{3}$ as compared to W\&M $\left(18.3 \pm 10.4 \mathrm{cfu} / \mathrm{m}^{3}\right)$ and $\mathrm{AC}\left(15.6 \pm 8.4 \mathrm{cfu} / \mathrm{m}^{3}\right) \mathrm{p}<0.05$. However, AC offices recorded the highest mean Total Fungi Count (TFC) of $3.6 \pm 2.3 \mathrm{cfu} / \mathrm{m}^{3}$ as compared to CA $\left(3.5 \pm 1.7 \mathrm{cfu} / \mathrm{m}^{3}\right)$ and W\&M $\left(3.3 \pm 2.1 \mathrm{cfu} / \mathrm{m}^{3}\right) \mathrm{p}>0.05$. The indoor TBC and TFC of the categories of offices were found to be lower than the AIHA guideline limit. The number of persons at the point of sampling was found to significantly predict the level of indoor $\mathrm{TBC}, \mathrm{p}<0.01$. The most isolated bacteria were Staphylococcus spp., Streptococcus spp. and Micrococcus spp., whereas Cladosporium spp., Aspergillus spp. were the most abundant fungi isolates. The present study implicated population as a major source of microbial contamination in the office environment. Adequate knowledge about indoor air quality in terms of microbial contamination and its implication on health should be provided to staff of the institution in the hierarchy of control measures to mitigate the levels of indoor airborne microorganisms.
\end{abstract}

Keywords: Indoor Air Quality, Microbial Load, Offices, Tertiary Institution, Nigeria

\section{Introduction}

Indoor air quality (IAQ) refers to the air quality within and around buildings and structures, especially as it relates to the health and comfort of building occupants. Occupational safety health administration (OSHA) recognizes that poor 
IAQ can be hazardous to workers' health and that it is in the best interest of everyone that building owners, managers and employers take a proactive approach to address IAQ concerns [1, 2]. In addition, an ageing population, an increasing number of sensitive individuals and a tendency to spend more time indoors (90\% of life time) further worsen this problem [3]. The quality of the environment within buildings is a topic of major importance for public health. The relationship between poor indoor air and workers productivity has also been documented. For instance, an employee who is on sick leave due to health problems caused by indoor air affects productivity of the company. This could result in the loss of work hours by the staff, medical costs, and increase in other employees' workload [4]. Good IAQ in buildings is therefore an important component of a healthy indoor environment, it contributes to a favourable and productive environment for building occupants, giving them a sense of comfort, health, and well-being [5]. Significant increases in worker productivity have also been demonstrated when the air quality is adequate [6]. Research has also shown that workers in buildings with adequate air quality have reduced rates of symptoms related to poor air quality [7]. This effect ranges from impacts on long-term job performance to short-term absence including, distractions and discomforts that impair cognitive thinking [8].

The growth of numerous species of bacteria and fungi, in particular filamentous fungi (mold), contributes significantly to indoor air pollution and has been linked to dampness [9]. Whenever sufficient moisture is present within workplaces, these microbes grow and predispose the workers to respiratory symptoms, allergies, and asthma. Air is an important necessity of life, however, little attention is often paid to the quality of air breathed in by most people during their daily routines in low and middle income countries (LMICs). While research has led to routine indoor monitoring and other interventions to improve IAQ in high income countries (HIC), not much has been documented on IAQ in resource poor settings like Nigeria. This assessment of the indoor microbial burden in offices is therefore necessary to help in assessing the IAQ and quantifying potential risk factors that predispose people to health risks. In addition, majority of people particularly office workers spend most of their time indoors [10] stressing the need for studies on indoor air quality especially in sub-Saharan Africa and Nigeria. This study was conducted to assess the indoor meteorological conditions and the level of microbial (bacterial and fungi) contamination of different offices in a tertiary institution in South-Western Nigeria.

\section{Methods}

\subsection{Study Design}

This study used a cross sectional design to compare the indoor meteorological conditions and airborne microbial load of selected offices in a tertiary institution in South-Western Nigeria.

\subsection{Study Area}

The study was carried out at a tertiary institution located in South-Western Nigeria. The institution occupies over 1,032 hectares of land and lies between latitude $3^{\circ} 53^{\prime} 54.35$ ' $\mathrm{E}$ and longitude $7^{\circ} 26^{\prime} 47.9^{\prime \prime} \mathrm{N}$. The institution is a beehive of activities which include; academic, administrative, social, construction/maintenance as well as domestic activities. These activities contribute to the upheaval energy utilization and emission profile observed within the community. The institution is made of thirteen (13) faculties and a college of medicine. The academic functions of the institution is to provide a learning, teaching and research environment for students.

This study was carried out from July - October, 2014, within the Central administrative (CA), Academic (AC) and work Maintenance (W\&M) buildings. The CA offices were designed to accommodate the administrative activities of staff members of the institution. These offices are usually occupied by academic as well as non-academic staff of the Institution. The CA is a complex building where administrative decisions of academic and non-academic policies, inquiry, planning and archiving are made. The W\&M are offices where workers fix and maintain machines, mechanical, building and electrical equipment, and repairing of air conditioning system. The AC offices are devoted to academic activities such as lectures, laboratories and office spaces of lecturers and departmental offices. These offices are nested in the faculties and departments.

\subsection{Selection of Offices}

A preliminary survey was carried out to obtain information on the total number of offices at the CA, AC and W\&M premises to generate baseline information. A purposive sampling of fifty (50) offices each at the CA, AC and W\&M premises was carried out and sampled for airborne microbial load.

\subsection{Onsite Survey of Offices}

A checklist was developed and used to assess the building characteristics and sanitary conditions of the offices. The checklist captured some environmental health indicators such as: status of building and building design, presence of old/deteriorated furniture, presence of materials containing asbestos, damp roof, sanitary conditions, waste management etc. The number of persons in the offices at the time of sampling was also recorded.

\subsection{Meteorological Parameter and Air Sampling}

Indoor temperature $\left({ }^{\circ} \mathrm{C}\right)$ and relative humidity $(\%)$ of the respective offices were measured using a 5-in-1 multimeter N21FR (Maplin, UK) and categorized into comfortable level (temperature; $25.2-<32.0^{\circ} \mathrm{C}$; and $\mathrm{RH}: 30.0-60.0 \%$ ) and high levels (temperature: $32.0-40.0^{\circ} \mathrm{C}$; and $\mathrm{RH}:>60 \%$ ) according to the scale of measurement used by Wolkoff and Kjaergaard [11] and Hassan and Ramli [12]. The level of carbon dioxide 
$\left(\mathrm{CO}_{2}\right)$ was measured using a calibrated $\mathrm{CO}_{2}$ meter. Air samples were collected using a TE-10-890 Andersen single stage microbial air sampler. The individual microbial agents were captured using prepared nutrient agar and potato dextrose agar. Air Sampling was carried out at a flow rate of $56.61 / \mathrm{min}$ for 20 minutes. The ambient and indoor measurements were determined at two periods of the day between $8 \mathrm{am}-11 \mathrm{am}$ and between $12 \mathrm{pm}-2 \mathrm{pm}$ at $1.5 \mathrm{~m}$ above the ground. Measurements were taken three days in a week for 16 weeks.

\subsection{Microbial Identification}

All agar plates were transported to the laboratory and incubated at $35^{\circ} \mathrm{C}-37^{\circ} \mathrm{C}$ for 48 hours for bacteria and room temperature for 5 days for fungi. After incubation, the total plate count was recorded. Bacterial identification was based primarily on morphology, hand lens was used to magnify the colonies and culture characteristics. Some commonly found bacterial was identified at the genus level using the national standard method. Light microscope was used to describe the colonial features and the morphological structures of the fungi. The determination of the morphological structures of fungi was carried out on material mounted in lactophenol. Fungi isolated was identified to genus level based on micromorphology and using the books by Barnett and Ellis.

\subsection{Data Management and Statistical Analysis}

Descriptive statistics (proportion, means, standard deviation and frequency tables) was used to summarize the data. Analyses were conducted using SPSS software version 15 (IBM SPSS Statistics). Building characteristics and conditions of all offices was classified as - (absent in only < $50 \%$ of offices), - - (absent in 100\% of offices), + (present in $<50 \%$ of offices), ++ (present in $50-80 \%$ of offices), +++ (present in 80-100\% of offices). The mean total bacterial count (TBC) and total fungal count (TFC) was calculated and compared with the American Industrial Hygiene Association (AIHA) guideline limit of $500 \mathrm{cfu} / \mathrm{m}^{3}$. T-test was used to compare mean differences of total bacterial count (TBC) and total fungal count (TFC) and other environmental parameters. Spearman's correlation analyses was used to test the relationships between environmental parameters, TBC and TFC. Regression analysis was used to determine the predictive effect of the environmental parameters on TBC and TFC.

\section{Results}

\subsection{Building Characteristics of Offices}

Table 1 shows the building characteristics and condition of offices sampled. Mold growth on the walls was present in more of the AC offices (present in $50-80 \%$ of office) as compared to CA (present in $<50 \%$ of offices) and W\&M (absent in $<50 \%$ of offices) offices. Also, old and deteriorating furniture were found to be present in more offices at the $\mathrm{AC}$ and $\mathrm{CA}$ as compared to W\&M. All the offices sampled at the $\mathrm{CA}$ and $\mathrm{AC}$ premises were found with dust on furniture. More than $50 \%$ of CA offices had damp roof compared to AC and W\&M. See table 1 for details.

Table 1. Building Characteristics and conditions of $W \& M, C A$ and $A C$ offices.

\begin{tabular}{llll}
\hline Building Condition & \multicolumn{2}{l}{ Location } \\
\cline { 2 - 4 } Observations & W\&M & CA & AC \\
\hline Presence of mold growth & - & + & ++ \\
Materials containing old asbestos & - & - & -- \\
Old or deteriorated furnishing & - & ++ & ++ \\
Dust on furnishing & + & ++ & +++ \\
Damp roof & + & ++ & + \\
\hline KEY & & & \\
$-:$ absent in only $<50 \%$ of offices; $--:$ absent in $100 \%$ of offices; + : present in \\
$<50 \%$ of offices; ++ : present in $50-80 \%$ of offices, $+++:$ present in $80-$ \\
$100 \%$ of offices
\end{tabular}

\subsection{Indoor Environmental Condition of the Offices}

Table 2 shows the indoor environmental conditions of offices sampled. The mean $\pm \mathrm{SD}$ indoor temperature of $\mathrm{AC}$ offices $\left(27.9 \pm 0.6^{\circ} \mathrm{C}\right)$ was slightly higher when compared to W\&M offices $\left(27.9 \pm 0.8^{\circ} \mathrm{C}\right)$ and $\mathrm{CA}$ offices $\left(27.9 \pm 0.6^{\circ} \mathrm{C}\right)$. All offices sampled were within the comfort level (25.2$33.0^{\circ} \mathrm{C}$ ) of temperature. Similarly, indoor RH of AC offices $(76.1 \pm 4.2 \%)$ was found to be higher than the other categories of offices. More than $90 \%$ of offices sampled within the three categories were within the high level $(>60 \%)$ of relative humidity. A significant difference was recorded in the mean $\mathrm{CO}_{2}$ levels across the categories of offices with $\mathrm{CA}$ offices having the highest level $(469.6 \pm 69.2 \mathrm{ppm})$. The mean number of persons in the office observed at the point of sampling was higher in the CA offices $(4.4 \pm 1.3$ persons $)$ than $\mathrm{AC}(1.9 \pm 0.8$ persons $)$ and $\mathrm{W} \& \mathrm{M}(1.3 \pm 0.6$ persons $)$, $\mathrm{p}<0.05$.

Table 2. Indoor Environmental Parameter across the categories of offices.

\begin{tabular}{|c|c|c|c|c|c|c|}
\hline Parameter & Office & N (\%) & Mean \pm SD & Min & Max & p-Value \\
\hline \multirow{3}{*}{ Temperature $\left({ }^{\circ} \mathrm{C}\right)$} & W\&M & $50(100 \%)$ & $27.87 \pm 0.75$ & 25.8 & 29.9 & \multirow{3}{*}{0.97} \\
\hline & $\mathrm{CA}$ & $50(100 \%)$ & $27.85 \pm 0.60$ & 26.1 & 29.0 & \\
\hline & $\mathrm{AC}$ & $50(100 \%)$ & $27.88 \pm 0.59$ & 26.8 & 29.1 & \\
\hline \multirow{3}{*}{ Relative humidity (\%) } & W\&M & $50(100 \%)$ & $74.18 \pm 8.72$ & 28.1 & 85.9 & \multirow{3}{*}{0.25} \\
\hline & $\mathrm{CA}$ & $50(100 \%)$ & $74.41 \pm 4.58$ & 64.5 & 84.0 & \\
\hline & $\mathrm{AC}$ & $50(100 \%)$ & $76.12 \pm 4.21$ & 67.6 & 85.5 & \\
\hline \multirow{3}{*}{ Carbon dioxide (ppm) } & W\&M & $50(100 \%)$ & $436.23 \pm 78.35$ & 311.0 & 775.0 & \multirow{3}{*}{0.00} \\
\hline & $\mathrm{CA}$ & $50(100 \%)$ & $469.56 \pm 69.24$ & 323.0 & 633.0 & \\
\hline & $\mathrm{AC}$ & $50(100 \%)$ & $398.56 \pm 70.31$ & 321 & 472 & \\
\hline Number of persons & W\&M & $50(100 \%)$ & $1.33 \pm 0.56$ & 1.00 & 3.00 & 0.00 \\
\hline
\end{tabular}




\begin{tabular}{|c|c|c|c|c|c|c|}
\hline Parameter & Office & N (\%) & Mean \pm SD & Min & $\operatorname{Max}$ & p-Value \\
\hline & CA & $50(100 \%)$ & $4.39 \pm 1.32$ & 1.00 & 7.00 & \\
\hline & $\mathrm{AC}$ & $50(100 \%)$ & $1.98 \pm 0.79$ & 1.00 & 3.00 & \\
\hline
\end{tabular}

$\mathrm{W} \& \mathrm{M}=$ Works and Maintenance

$\mathrm{CA}=$ Central Administration

$\mathrm{AC}=$ Academics

\subsection{Indoor Airborne Total Bacterial Count (TBC) and Total Fungal Count (TFC) in Selected Offices}

Figures 1-2 shows the standard error of mean TBC and TFC for selected offices compared with the American Industrial Hygiene Association (AIHA) guideline limit for indoor microbial load. CA recorded the highest mean indoor TBC of $22.61 \pm 12.15 \mathrm{cfu} / \mathrm{m}^{3}$ compared to W\&M (18.33 \pm $\left.10.44 \mathrm{cfu} / \mathrm{m}^{3}\right)$ and $\mathrm{AC}\left(15.56 \pm 8.44 \mathrm{cfu} / \mathrm{m}^{3}\right) \quad \mathrm{p}<0.05$. In contrast, AC had the highest mean TFC of $3.58 \pm 2.26 \mathrm{cfu} / \mathrm{m}^{3}$ compared to $\mathrm{CA}\left(3.45 \pm 1.56 \mathrm{cfu} / \mathrm{m}^{3}\right)$ and $\mathrm{W} \& \mathrm{M}(3.32 \pm$ $\left.2.14 \mathrm{cfu} / \mathrm{m}^{3}\right) \quad \mathrm{p}>0.05$. The indoor TBC and TFC of the categories of offices were found to be lower than the AIHA guideline limit.

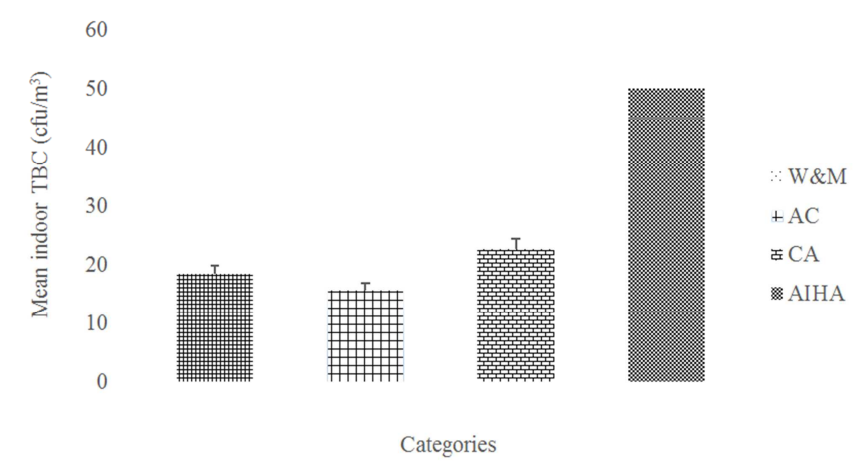

Figure 1. Mean indoor Total Bacterial Counts (TBC) of selected offices versus AIHA guideline limits.

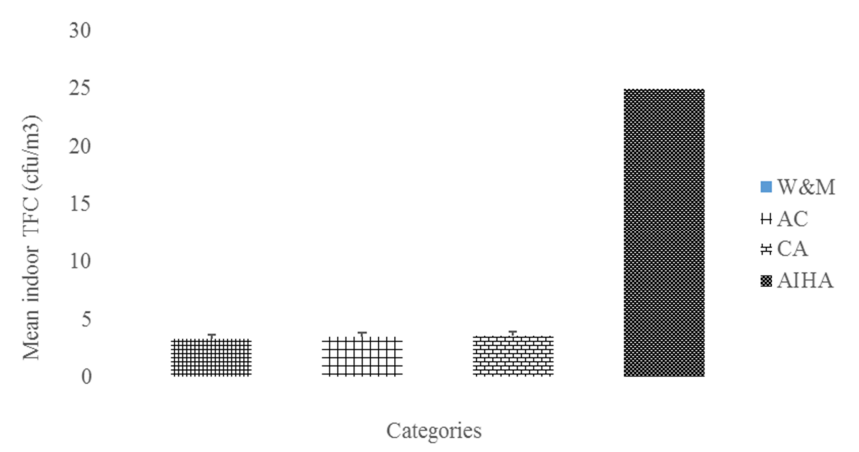

Figure 2. Mean indoor Total Fungal Counts (TFC) of selected offices versus AIHA guideline limits.

\subsection{Relationship Between Indoor Environmental Parameters of Selected Offices and Microbial Load}

The indoor temperature of selected offices was inversely correlated with indoor relative humidity ( $\mathrm{rs}=-0.46)$ but moderately correlated with indoor total fungal count ( $\mathrm{rs}=$ 0.15 ). The number of persons at the point of sampling was also moderately correlated with indoor TBC (rs $=0.19)$ and indoor $\mathrm{CO}_{2}(\mathrm{rs}=0.18)$ (see Table 3 for detail). Table 4 shows a regression analysis to determine the predictors of indoor TBC. The number of persons in the room at the time of sampling was found to predict the level of indoor TBC, $\mathrm{p}<0.01$.

Table 3. Spearman's correlation between indoor environmental parameters and indoor microbial load.

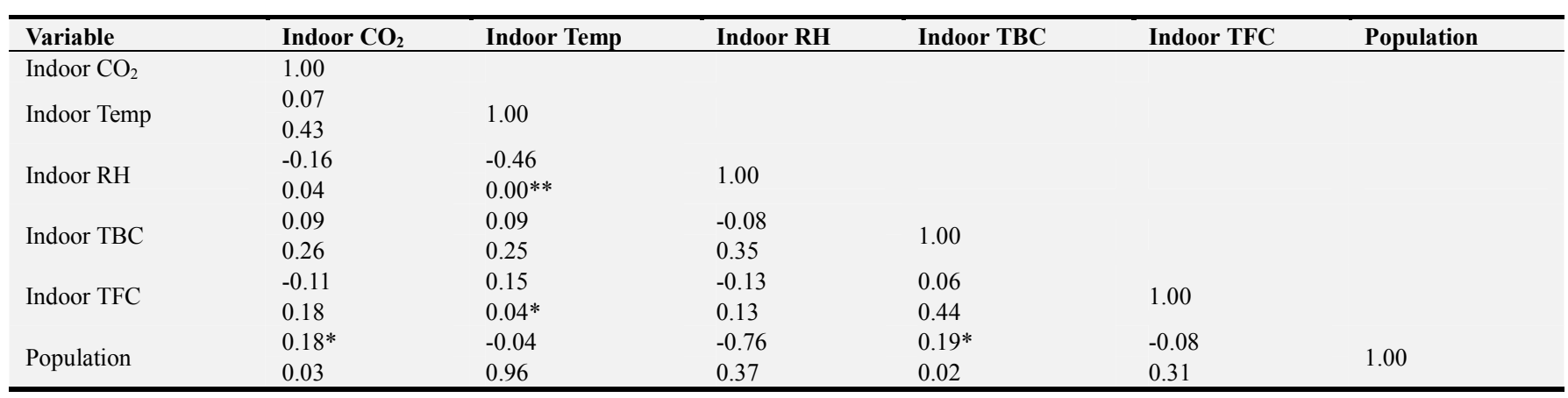

$\mathrm{n}=50 ; * *=\mathrm{p}<0.01 ; *=\mathrm{p}<0.05$

Table 4. Regression analysis with the parameters (predictor) and Indoor Total Bacterial Count as the dependent variable.

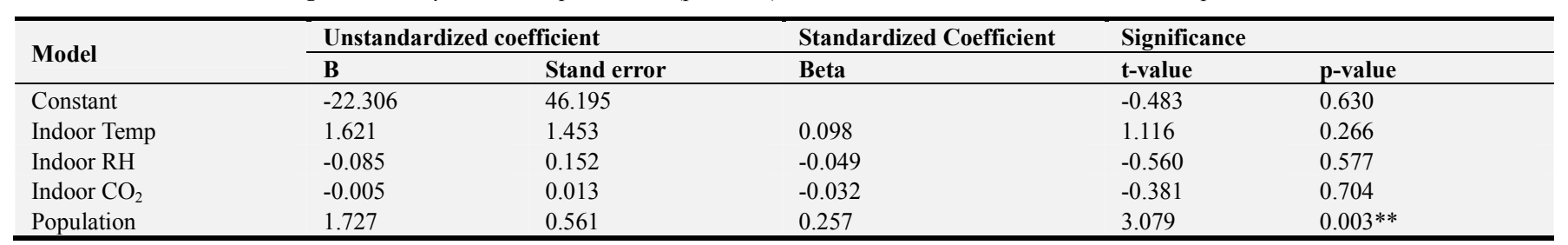

$* *=\mathrm{p}<0.01$ 


\subsection{Profile of Airborne Microorganisms Isolated from the Indoor Environment of Selected Offices}

The most isolated bacteria were Staphylococcus spp., Streptococcus spp. and Micrococcus spp., whereas to a lesser extent Bacillus spp. and Pseudomonas spp. were isolated. The most detected fungi were filamentous species with cotton-like appearance. They include, Cladosporium spp., Aspergillus spp., Penicillium spp., Fusarium spp., and Candida spp. in descending order of abundance.

\section{Discussions}

The study of airborne microorganisms in indoor environments is important to understand the spread of airborne microbes particularly the pathogenic organisms. The abundance and diversity of airborne microorganisms can be useful in determining the degree of cleanliness and the environment's potential to constitute a health hazard [13]. The presence of damp roof and mould growth was recorded in most of the offices screened in CA and AC. This suggests water leakages into the buildings from the outdoor environment or from indoor faulty plumbing. According to a similar study by [14], dampness was defined on the basis of self-reported indicators, such as water leakage or water damage and visible mould growth on walls, floors or ceilings. The number of persons observed during sampling was found to be more in the offices samples within the CA premises. This was obviously due to the fact that the CA offices were established to entertain students' complaints and enquiries thereby allowing free inflow of academic and nonacademic individuals within and outside the institution into the offices. The relative humidity observed in most of the offices was above the comfort level according to Wolkoff and Kjaergaard, [11]. The high indoor relative humidity observed in most of the offices could be due to high moisture levels which confirmed the damp situation recorded in the offices. With such high-relative humidity levels, microorganisms such as fungi and bacteria can survive on non-living materials including dust [15].

The findings from this study revealed that, the indoor bacterial load of offices visited among CA was higher than values obtained for W\&M and AC. The high bacterial load could be due to the number of persons occupying the rooms which was found to be more in the CA offices. It could also be due to poor design or inadequate ventilation, although, the load recorded was within the acceptable limit proposed by the American Industrial Hygiene Association [16]. A similarly study carried out by Ana et al. [17] recorded the highest bacterial burden in an overcrowded environment due to the facts that airborne bacterial were dispersed into the air from crowded groups of people. Therefore, the airborne microorganisms could be said to be of human origin. Similarly, Bartlett et al., [18] found that occupants contribute to the concentration of indoor airborne bacterial and the individual concentration of bacterial such as Micrococci and
Staphylococci are related to occupancy or occupants activity. This suggests that the number of persons in the indoor environments is directly proportional to the level of bacteria build-up in the indoor environment [19]. A study carried out by Samuel and Abayneh [20] also reported that the concentrations of bacteria measured in seven libraries in Jimma Universities (Ethiopia) were significantly different from each other. He further explained that these differences were explained by the variation of density of occupant during the sampling time as well as the variation of ventilation condition.

This study also found that the predominant bacteria species observed in the indoor environment of offices were grampositive bacteria such as Micrococcus spp, Staphylococcus spp, Streptococcus spp and Bacillus spp. This corroborates the findings of Ana et al., [21] on indoor airborne microbial burden and risk of acute respiratory infections among under five children in Ibadan, Nigeria. A similar study carried out by Yassin et al., [22] found that most of the bacterial isolated from the indoor and outdoor environments were grampositive bacterial. Majority of these bacterial occur in most environments; particularly in dusty, unsanitary places inhabited by humans [23]. A large proportion of these bacteria isolated from the offices are normal flora of such environments and non-pathogenic [22]. Furthermore, most of the fungal species isolated like Penicillium spp. and Aspergillus spp., are recognized opportunistic pathogens for humans and are often associated with clinical manifestations such as allergic rhinitis, asthma and allergic conjunctivitis [20]. Aspergillus spp, Fusarium spp, and Penicillium spp which were isolated from this study can cause type 1 hypersensitivity according to Malgorzak et al [17].

\section{Conclusions}

The present study implicated more occupied or overcrowded workplace as major source of microbial contamination in the indoor environment. The Central Administrative offices had higher number of persons at the point of sampling which suggests the higher burden of bacterial contamination, however, the indoor total bacterial and fungal counts were below the acceptable threshold by the American Industrial Hygiene Association (AIHA). Two of the fungal species found in the offices (Aspergillus spp and Penicillium spp) were classified as high risk group responsible for allergies and hypersensitivity reactions which could be potentially hazardous. In the light of the findings from this study, it is recommended that staff of the institutions should be adequately informed about the place of clean indoor conditions, improved sanitary practices and effective ventilation in the hierarchy of control measures to mitigate the levels of indoor airborne microorganisms. Employers should also ensure that offices spaces are well ventilated and not overcrowded. A culture of maintain infrastructure should also be established to prevent leakage and malfunction of cooling systems that will make the 
working environment more conductive for workers and reduce the temperature and relative humidity which will prevent growth of microbial organisms. A major limitation of this study was the inability to molecularly characterize the microbial isolates which would have helped in identifying the organisms to specie level in order to determine the tolerance levels of these organisms toward commonly used antibiotics that are used to treat respiratory diseases caused by indoor microorganisms. Nevertheless, and to the best of our knowledge, the findings from this study would serve as the basis for an in-depth indoor airborne micro-floral assay in the future. Thus microbiological air quality is an important criterion that must be taken into account when indoor workplaces are designed to provide a safe environment

\section{Authors' Contribution}

AOO, AGR and FAG designed the study and planned analyses. AGR supervised the study. FAG and AOO wrote the first draft of the report. FAG performed the statistical analyses. All authors contributed to the collection, discussion and interpretation of the data, and to the review of the manuscripts.

\section{References}

[1] Occupational Safety and Health Administration (2011) Indoor Air Quality in Commercial and Institutional Buildings, OSHA Publication 3430-04.

[2] Huboyo HS, Tohno S, and Cao R (2011) Indoor PM Characteristics and CO Concentration Related to Water-based and Oil-based Cooking Emissions Using a Gas Stove. Aerosol Air Qual. Res. 11: 401-411.

[3] Tringe SG, Zhang T, Liu X, Yu Y. Lee WH, Yap J, et al (2008) The airborne metagenome in an indoor urban environment. PLoS ONE, 3, 1-10.

[4] Antikainen R, Lappalainen S, Lonnqvist A (2008) Exploring the relationship between indoor air and productivity. SJWEH Suppl, 4:79-82.

[5] David PW, Pawel W (2013) Effect of indoor environment on performances. ASHRAE Journal pp 46-50.

[6] Singh A, Syal M, Grady SC,. Korkmaz K (2010) effect of green building on employee health and productivy. Am. J. Public Health 100(9) P.1665.

[7] Malgorzata Golofit-Szymczak. Rafat, L. Gorny (2010) Bacterial and Fungal Aerosols in Air-Conditioned Office Buildings in Warsaw, Poland- The Winter Season. International Journal of Occupational Safety and Ergonomics (JOSE), 16.4: 465-476.

[8] Ajimatokin, HA, (2009). Influence of Indoor Environment on Health and Productivity. New York Science Journal, 2(4): 1554-02020
[9] World Health Organization (2009) WHO Guideline for indoor air quality; dampness and Mould.

[10] Komalanathan Vimalanathan and Thangavelu Ramesh Babu (2014). The effect of indoor office environment on the work performance, health and well-being of office workers. Journal of Environmental Health Science and Engineering; 12:113.

[11] Wolkoff P and Kjaergaard SK (2007) The dichotomy of relative humidity on indoor air quality. Environ Int; 33: 850857.

[12] Hassan AS and Ramli M (2010) Natural ventilation of indoor air temperature: A case study of the traditional malay house in Penang. Am J Eng Appl Sci; 3(3): 521-528.

[13] Ekhaise FO, and Ogboghodo BI (2011) Microbiological Indoor and Outdoor Air Quality of Two Major Hospitals in Benin City, Nigeria. Journal of Biomedical Research ISSN 2076-6270 (Print) 3.3:169-174.

[14] Mudarri, D. and Fisk, W. J. (2007). public health and economic impact of dampness and mold. Indoor Air. Blackwell publishing, Malden, MA, 17(3):226-235.

[15] Choa HJ, Schwartz J, Milton DK and Burge HA (2002) Populations and determinants of airborne fungi in large office buildings. Environ Health Perspect; 110: 777-782.

[16] American Industrial Hygiene Association (AIHA) (2001) Report of microbial growth task force. From http://www.hcsc.gc.ca/ewh-semt/pubs/air/fungal-fongique/referenceseng.php (retrieved 25 January 2018). Fairfax, VA1.

[17] Ana G. R., Fakunle A. G., Ogunjobi A. A. (2015). Indoor Airborne Microbial Burden and Risk of Acute Respiratory Infections among Children under-five in Ibadan, Nigeria. Indoor and Built Environment, 24(3): 308-314.

[18] Bartlett, K. H., Kennedy, S. M., Brauer, M., van Netten, C. and Dill, B. (2004), Evaluation and determinants of airborne bacterial concentrations in school classrooms. J. Occup. Environ. Hyg., 1, 639-647.

[19] Wemedo SA,. Ede PN, and Chuwku A (2012) Interaction between Building Design and Indoor Airborne Microbial load in Nigeria. Asian Journal of Biological Sciences, 5: 183-191.

[20] Samuel FH, Abayneh MM (2014) Microbiological Quality of Indoor Air in University Libraries. Asia Pac J. Trop. Biomed (Supp 1) S312-S317.

[21] Ana GRE, Zainab, O. Umar (2013) Inhalable particulate matter burden in selected day-care centres in Ibadan, Nigeria. International Journal of Environmental Monitoring and analysis, 1.6: 296-301.

[22] Yassin, M. F. Almouqatea, S (2010) Assessment of airborne bacteria and fungi in an indoor and outdoor environment. Int.J. Environ. Sci.Tech, 7.5: 535-544.

[23] Hospodsky D, Qian J, Nazaroff WW, Yamainoto N, Bibby K, and Rismani-Yazdi H (2012) Human occupancy as a source of indoor airborne bacteria: Plosone, 7:e348. 